\title{
LEGITIMASI HUKUM PEMBERLAKUAN SYARI'AT ISLAM DI ACEH: Tinjauan Yuridis, Sosiologis dan Filosofis
}

\section{Jafar}

STAIN Malikussaleh Lhokseumawe, Aceh

Email: asyibriqi@yahoo.com

\begin{abstract}
The glory of Aceh Darussalam Kingdom in the past cannot be separated from the complete application of Islamic Sharia (kaffah) as the way of life in Aceh. Reflecting the historical past, the implementation of Sharia in Aceh in the present context is absolutely necessary. However, today's enforcement must refer to the three foundations, namely judicial, sociological, and philosophical. The most fundamental of juridical basis is the Constitution of 1945 (UUD 1945) Chapter XI on Religion and paragraph 2 of Article 29, new amendment of Article 18A paragraph 1 and Article 18B paragraph 1. The implementing of Sharia law in Aceh began with the birth law No. 44/1999 regarding the Implementation Features Special of Aceh Province, then refined by law No. 18/2001 on Special Autonomy for Aceh Province as Nanggroe Aceh Darussalam province. Then it is continued by the Law Number 11/2006 on the Governing of Aceh (UUPA). The sociological ground is majority Muslim of Acehnese can receive all the products based on Islamic Sharia law. The philosophical foundation, Islamic law, should be enforced based on the Qur'an and Hadith recommended preserving religion, life, property, lineage, and resourceful.
\end{abstract}

Keywords: Legitimacy law, Islamic Sharia, juridical, sociological and philosophical.

DOI: http://dx.doi.org/10.20414/ujis.v19i1.1250

\section{Pendahuluan}

SEPANJANG sejarah, masyarakat Aceh telah menjadikan agama Islam sebagai pedoman dalam kehidupannya. Penghayatan dan pengamalan ajaran Islam dalam rentang sejarah yang cukup panjang itu telah melahirkan suasana masyarakat dan budaya 
Aceh yang Islami, budaya dan adat yang lahir dari renungan para ulama, kemudian dipraktikkan, dikembangkan, dan dilestarikan oleh masyarakat. Bahkan dalam perjalanan sejarah mulai abad ke-17 sampai dengan pertengahan abad ke-19, Nanggroe Aceh Darussalam (NAD) mencapai puncak kejayaannya dalam bidang ilmu pengetahuan, politik, hukum, pertahanan, dan ekonomi. Puncak keemasan NAD tersebut tidak dapat dilepaskan dari pemberlakuan syariat Islam secara käffah sebagai pedoman hidup rakyat NAD dalam segala aspek kehidupan bermasyarakat, berbangsa dan bernegara. Kondisi tersebut tercermin dalam ungkapan bijak, "Adat bak Poteumeureuhom, Hukom bak Syiah Kuala, Qanun bak Putroe Phang, Reusam bak Laksamana" (Adat pada Sultan, Hukum pada ulama, Qanun pada Puteri Pahang/pemerintah, Resam pada Laksamana). Ungkapan tersebut merupakan pencerminan bahwa syariat Islam telah menyatu dan menjadi pedoman hidup bagi masyarakat Aceh melalui peranan para ulama sebagai pewaris para rasul. ${ }^{1}$

Sementara itu, sejak pertengahan abad ke-20, baik karena alasan internal maupun eksternal, syariat Islam mulai ditinggalkan sebagai pedoman dalam kehidupan bermasyarakat, berbangsa, dan bernegara. Bersamaan dengan kondisi demikian, rakyat Aceh menuju masa-masa suram dan sampai sekarang dalam kondisi yang sungguh memprihatinkan. Selama itu pula sebagai rakyat NAD merindukan berlakunya kembali syariat Islam yang dapat mengantarkan negeri ini untuk meraih kejayaannya dan berada pada posisi baldah tayyibah wa rabb gafür.

Oleh karena demikian, tulisan ini ingin penulis fokuskan pembahasannya mengenai legitimasi hukum pelaksanaan syariat Islam di Aceh ditinjau dari aspek yuridis, sosiologis, dan filosofis. Tujuannya adalah supaya jelas dasar pemberlakuan qanun tentang syariat Islam ditinjau dari ketiga aspek tersebut.

\section{Qanun Syariat Islam di Aceh Ditinjau Secara Yuridis}

${ }^{1}$ Dinas Syariat Islam, Himpunan Undang-undang, Keputusan Presiden, Peraturan Daerah/Qanun, Instruksi Gubernur, Edaran Gubernur Berkaitan Pelaksanaan Syariat Islam, Edisi 7 (Banda Aceh: Dinas Syariat Islam Aceh, $2009), 311$. 
Menurut Bagir Manan sebagaimana dikutip oleh Yuliandri, ${ }^{2}$ dalam pembentukan peraturan perundang-undangan, haruslah mengacu pada landasan pembentukan peraturan perundangundangan, yang di dalamnya terdiri landasan yuridis, sosiologis, dan filosofis. Dengan landasan yuridis, setiap produk hukum, mempunyai dasar berlakunya secara yuridis (juridische gelding). Dasar yuridis ini sangat penting dalam pembuatan peraturan perundang-undangan (termasuk peraturan daerah/qanun di Aceh), karena akan menunjukkan:

1. Keharusan adanya kewenangan dari pembuat produkproduk hukum. Setiap produk-produk hukum harus dibuat oleh pejabat yang berwenang. Kalau tidak, produk-produk hukum itu batal demi hukum (van rechtswegenietig) atau dianggap tidak pernah ada dan segala akibatnya batal demi hukum.

2. Keharusan adanya kesesuaian bentuk atau jenis produkproduk hukum dengan materi yang diatur, terutama kalau diperintahkan oleh peraturan perundang-undangan yang tingkatannya lebih tinggi atau sederajat. Ketidaksesuaian bentuk atau jenis dapat menjadi alasan untuk membatalkan atau dapat dibatalkan (vernietigbaar) produk hukum tersebut.

3. Keharusan mengikuti tata cara tertentu, apabila tata cara tertentu yang diharuskan tidak diikuti, maka produk-produk hukum tersebut belum mempunyai kekuatan hukum mengikat dan dapat dibatalkan demi hukum.

4. Keharusan tidak bertentangan dengan peraturan perundangundangan yang lebih tinggi tingkatannya.

5. Produk-produk hukum yang dibuat untuk umum dapat diterima oleh masyarakat secara wajar bahkan spontan.

Landasan yuridis yang paling mendasar atas pemberlakuan Syariat Islam di Aceh adalah Undang-Undang Dasar 1945 (UUD 1945) Bab XI tentang Agama, ayat 2 Pasal 29 yang berbunyi, "Negara menjamin kemerdekaan tiap-tiap penduduk untuk

2Yuliandri, Asas-Asas Pembentukan Peraturan Perundang-undangan Yang Baik: Gagasan Pembentukan Undang-Undang Berkelanjutan (Jakarta: RajaGrafindo Persada, 2010), 134. 
memeluk agamanya masing-masing dan untuk beribadat menurut agamanya dan kepercayaannya itu". ${ }^{3}$

Dasar dari pasal ini, maka pemberlakuan Syariat Islam di Aceh mutlak diperlukan karena mengingat latarbelakang masyarakat Aceh yang mayoritas muslim taat. Masyarakat Aceh maju peradabannya pada zaman kerajaan Aceh Darussalam dulu karena perberlakuan Syariat Islam dalam seluruh aspek kehidupannya. Pemberlakuan Syariat Islam di Aceh merupakan suatu keniscayaan untuk mengulang kembali masa kejayaan dan kemakmuran masyarakat pada masa lalu.

Selanjutnya, Pasal 18A ayat 1 UUD 1945 berbunyi, "Hubungan wewenang pemerintah pusat dan pemerintah daerah provinsi, kabupaten, dan kota diatur dengan undang-undang dengan memperhatikan kekhususan dan keberagaman daerah". Begitu juga Pasal 18B ayat (1) berbunyi, "Negara mengakui dan menghormati satuan-satuan pemerintah daerah yang bersifat khusus atau bersifat istimewa yang diatur dengan undangundang". ${ }^{4}$

Kedua pasal ini mengisyaratkan pemberlakuan Syariat Islam di Aceh sebagai daerah khusus atau daerah istimewa sebagaimana yang telah diamanahkan oleh undang-undang. Oleh karena demikian pemberlakuan syariat Islam di Aceh secara legitimasi yuridis sudah sangat jelas. Pemerintah pun telah mengakomodirnya di dalam berbagai undang-undang berikutnya. Tinggal saja di lapangan, apakah pemerintah daerah di Aceh ikhlas melaksanakannya atau tidak?.

Usaha pemberlakuan syariat Islam di Aceh diawali dengan lahirnya UU No. 44 Tahun 1999 tentang Penyelenggaraan Keistimewaan Provinsi Daerah Istimewa Aceh. Pemberian keistimewaan ini merupakan pengakuan dari bangsa Indonesia yang diberikan kepada daerah Aceh karena perjuangan dan nilainilai hakiki masyarakat yang tetap terpelihara secara turun temurun sebagai landasan spiritual, moral, dan kemanusiaan. Keistimewaan yang diberikan kepada Aceh ini mencakup: (a)

3Dien (Okumura), "Undang-undang Dasar Republik Indonesia 1945, Penabur Ilmu (Amandemen Oktober 1999 dan Agustus 2000)", http:/ / www.yorozu.indosite.org/const/ und45; diakses tanggal 26 Desember 2012.

${ }^{4}$ Ibid. 
penyelenggaraan kehidupan beragama, (b) penyelenggaraan kehidupan adat, (c) penyelenggaraan pendidikan, dan (d) peran ulama dalam penetapan kebijakan daerah (Pasal 3 Bab III UU No. 44 Tahun 1999). ${ }^{5}$

Pemberian keistimewaan ini sangat bersinggungan dengan UU No. 22 Tahun 1999 tentang Pemerintahan Daerah yang menetapkan bahwa semua urusan penyelenggaraan pemerintahan diserahkan kepada daerah, kecuali urusan pertahanan-keamanan, hukum, moneter, politik luar negeri, dan agama. Persinggungan ini setidaknya dalam bidang-bidang hukum dan agama. Sebagai contoh, Perda (Qanun) Provinsi Daerah Istimewa Aceh No. 5 Tahun 2000 tentang Pelaksanaan syariat Islam. Menurut Perda ini syariat Islam adalah tuntunan aturan Islam dalam semua aspek kehidupan (Pasal 1 angka 6 Perda 5/2000). Berdasarkan Perda Provinsi Daerah Istimewa Aceh No. 5 Tahun 2000 tentang Pelaksanaan Syariat Islam ini, keberadaan agama lain di luar agama Islam tetap diakui di daerah ini, dan pemeluknya dapat menjalankan agamanya masingmasing (Pasal 2 ayat 2). Syariat Islam meliputi akidah, ibadah, muamalah, akhlak, pendidikan dan dakwah Islamiyah/amar ma'ruf nahi munkar, baitul mal, kemasyarakatan, syiar Islam, pembelaan Islam, qadha', jinayah, munakahah, dan mawaris (Pasal 5 ayat 2$){ }^{6}$

UU No. 18 Tahun 2001 tentang Otonomi Khusus bagi Provinsi Daerah Aceh sebagai Provinsi NAD menetapkan Mahkamah Syar'iyah sebagai Peradilan Syariat Islam dengan kompetensi absolut meliputi seluruh aspek syariat Islam yang akan diatur dengan qanun. Di samping itu pada tingkat daerah, pelaksanaan syariat Islam telah dirumuskan secara yuridis melalui Peraturan Daerah Nomor 3 Tahun 2000 tentang Pembentukan Organisasi dan Tata Kerja Majelis Permusyawaratan Ulama (MPU) Propinsi Daerah Istimewa Aceh yang telah diubah

${ }^{5}$ Choiruddin Shobari, dkk., "Penyerapan Nilai-nilai Budaya Lokal dalam Kehidupan Beragama di Aceh (Studi Tentang Budaya Lokal di Aceh)", dalam Harmonisasi Agama dan Budaya di Indonesia (2), ed. Afif dan Saiful Bahri (Jakarta: Balai Penelitian dan Pengembangan Agama, 2009), 354.

${ }^{6}$ Dinas Syariat Islam, Himpunan Undang-Undang ..., 259-60. 
Peraturan Daerah Nomor 43 Tahun 2001 tentang Perubahan Pertama atas Peraturan Daerah Nomor 3 Tahun 2000 tersebut. $^{7}$

Qanun Provinsi NAD No. 10 Tahun 2002 tentang Peradilan Syariat Islam menyebutkan bahwa Mahkamah Syar'iyah memiliki wewenang untuk memeriksa dan memutuskan perkara dalam bidang: (a) abwal al-syakbiiyah, (b) mu'amalah dan (c) jinayah (Pasal 49 Qanun 10/2002). ${ }^{8}$ Ini salah satu keistimewaan qanun yang berwenang membentuk lembaga peradilan setingkat dengan Peradilan tingkat pertama dan Peradilan Tinggi, yang tidak dimiliki oleh Qanun No. 11 Tahun 2002 tentang Pelaksanaan Syariat Islam bidang akidah, ibadah, dan syiar Islam.

Selanjutnya, ada Qanun Nomor 12 Tahun 2002 tentang Minuman Khamar dan Sejenisnya, Qanun Nomor 13 Tahun 2002 tentang Maisir (Perjudian), dan Qanun Nomor 14 Tahun 2002 tentang Khalwat (Mesum). Semua qanun ini secara yuridis merupakan pengembangan dari undang-undang dan qanun sebelumnya tentang syariat Islam.

Jadi, sebenarnya pelaksanaan syariat Islam di Aceh sudah diberikan oleh pemerintah pusat sejak tahun 1959 berdasarkan Keputusan Perdana Menteri RI Nomor 1/Missi/1959 tentang Keistimewaan Propinsi Aceh meliputi agama, peradatan, dan pendidikan. Namun, pemerintah menyadari bahwa keistimewaan yang diberikan kepada Aceh itu tidak memiliki peraturan pelaksanaan yang memungkinkannya dijalankan di tengah masyarakat. Oleh karena itu, pemerintah mengeluarkan UndangUndang Nomor 44 Tahun 1999 tentang Penyelenggaraan Keistimewaan Daerah Istimewa Aceh. Kelihatannya dengan UU itu pemerintah mengoreksi kebijakan sebelumnya yang cenderung mengabaikan pengorbanan, kesetiaan dan hak-hak khusus Aceh yang sejak lama telah diakui dan dibanggakan. ${ }^{9}$

Selanjutnya, lahir Undang-Uundang Nomor 18 Tahun 2001 tentang Otonomi Khusus bagi Provinsi Daerah Aceh sebagai Provinsi Nanggroe Aceh Darussalam. Aturan mengenai

7Ibid., 312.

8Ibid., 287.

${ }^{9} \mathrm{Al}$ Yasa' Abubakar, Syariat Islam di Provinsi Nanggroe Aceh Darussalam; Paradigma, Kebijakan dan Kegiatan, Edisi 5, (Banda Aceh: Dinas Syariat Islam Provinsi NAD, 2008), 43-4. 
pelaksanaan syariat Islam dalam undang-undang ini merupakan kelanjutan serta penyempurnaan terhadap apa yang telah diatur dalam undang-undang UU No. 44 Tahun 1999. Keistimewaan yang diberikan kepada Aceh sebagai tambahan dalam UU No. 18 Tahun 2001 ini adalah pembentukan lembaga peradilan khusus untuk melaksanakan syariat Islam, yaitu Mahkamah Syar'iyah (Pasal 25). Mahkamah Syar'iyah Kabupaten/Kota sebagai lembaga pengadilan tingkat pertama dan Mahkamah Syar'iyah Provinsi sebagai lembaga pengadilan tingkat banding. Sedangkan pengadilan tingkat kasasi akan dilakukan oleh Mahkamah Agung (Pasal 26 ayat 2). ${ }^{10}$

Terakhir, disahkannya Undang-Undang Nomor 11 Tahun 2006 tentang Pemerintahan Aceh (UUPA). Dalam UUPA ini terdapat tiga pasal khusus yang mengatur dan mengamanahkan pemberlakuan syariat Islam di Aceh. Ketiga pasal itu merupakan bagian dan isi dari bab XVII tentang syariat Islam dan Pelaksanaannya, yaitu Pasal 125, 126 dan 127.

Pasal 125 terdiri dari 3 ayat, yaitu:

(1) Syariat Islam yang dilaksanakan di Aceh meliputi akidah, syariah, dan akhlak.

(2) Syariat Islam sebagaimana dimaksud pada ayat (1) meliputi ibadah, abwāl al-shaksiyyah (hukum keluarga), mu'ämalah (hukum perdata), jināyah (hukum pidana), qadä' (peradilan), tarbiyyah (pendidikan), dakwah, syiar, dan pembelaan Islam.

(3) Ketentuan lebih lanjut mengenai pelaksanaan syariat Islam sebagaimana dimaksud pada ayat (1) diatur dengan Qanun Aceh.

Pasal 126 terdiri dari dua ayat, yaitu:

(1) Setiap pemeluk agama Islam di Aceh wajib menaati dan mengamalkan syariat Islam.

(2) Setiap orang yang bertempat tinggal atau berada di Aceh wajib menghormati pelaksanaan syariat Islam.

Pasal 127 terdiri dari lima ayat, yaitu:

(1) Pemerintahan Aceh dan pemerintahan kabupaten/kota bertanggung jawab atas penyelenggaraan pelaksanaan syariat Islam.

${ }^{10}$ Ibid., 48-50. 
(2) Pemerintahan Aceh dan pemerintahan kabupaten/kota menjamin kebebasan, membina kerukunan, menghormati nilai-nilai agama yang dianut oleh umat beragama dan melindungi sesama umat beragama untuk menjalankan ibadah sesuai dengan agama yang dianutnya.

(3) Pemerintah, Pemerintahan Aceh dan pemerintahan kabupaten/kota mengalokasikan dana dan sumber daya lainnya untuk pelaksanaan syariat Islam.

(4) Pendirian tempat ibadah di Aceh harus mendapat izin dari Pemerintah Aceh dan/atau pemerintah kabupaten/kota.

(5) Ketentuan lebih lanjut mengenai pemberian izin sebagaimana dimaksud pada ayat (4) diatur dengan qanun yang memperhatikan peraturan perundang-undangan.

UU itu dengan jelas memberikan hak kepada pemerintah Aceh untuk melaksanakan syariat Islam di bumi Serambi Mekkah. Implementasinya diatur oleh qanun-qanun yang dibuat oleh pemerintah Aceh sendiri. Jadi, secara legitimasi yuridis pelaksanaan syariat Islam di Aceh sudah jelas dan lengkap untuk dijalankan oleh yang berwenang dengan menyusun qanun-qanun pendukungnya secara lengkap.

\section{Qanun Syariat Islam di Aceh Ditinjau Secara Sosiologis}

Selain landasan yuridis, suatu produk hukum harus memiliki landasan sosiologis (sociologiche gelding) yang mencerminkan kenyataan yang hidup dalam masyarakat. Kenyataan itu dapat berupa kebutuhan atau tuntutan atau masalah-masalah yang dihadapi, seperti masalah perburuhan, kebersihan, ketertiban dan lain sebagainya. Selanjutnya, dengan dasar sosiologis, diharapkan suatu peraturan perundang-undangan yang dibuat dapat diterima oleh masyarakat secara wajar dan spontan. Peraturan perundangundangan yang diterima secara wajar akan mempunyai daya berlaku efektif dan tidak begitu banyak memerlukan pengerahan institusional untuk melaksanakannya. ${ }^{11}$

Kenyataan yang hidup dalam masyarakat sebagai dasar sosiologis harus termasuk pula kecenderungan-kecenderungan dan harapan-harapan masyarakat. Tanpa memasukkan faktorfaktor kecenderungan dan harapan, maka peraturan perundang-

11Yuliandri, Asas-Asas Pembentukan ..., 135. 
undangan akan tertinggal dari dinamika masyarakat, bahkan akan menjadi konservatif. Padahal peraturan perundang-undangan diharapkan mengarahkan perkembangan masyarakat. ${ }^{12}$

Menurut Lawrence M. Friedmann sebagaimana dikutip oleh Abdul Manan, ${ }^{13}$ setiap sistem hukum mengandung tiga komponen, yaitu komponen struktural, substansial, dan kultural. Komponen struktural adalah mencakup berbagai institusi yang diciptakan oleh sistem hukum tersebut dengan berbagai macam fungsinya dalam rangka mendukung bekerjanya sistem tersebut. Sedangkan komponen substansial adalah mencakup segala apa yang merupakan keluaran dari suatu sistem hukum. Dalam pengertian ini termasuk norma hukum yang berupa peraturan perundang-undangan, doktrin-doktrin sejauh semuanya itu dipergunakan dalam proses bekerjanya hukum. Komponen yang ketiga adalah budaya hukum atau disebut dengan "the legal culture", yaitu keseluruhan faktor yang menentukan bagaimana sistem hukum memperoleh tempatnya yang logis dalam kerangka budaya milik masyarakat umum. Jadi budaya hukum adalah tidak lain dari sikap masyarakat dan sistem nilai yang ada dalam masyarakat yang akan menentukan bagaimana seharusnya hukum itu berlaku dalam masyarakat.

Budaya hukum berkait erat dengan dan tidak bisa dipisahkan dari kesadaran hukum. Untuk mengenal tentang budaya hukum dan kesadaran hukum masyarakat perlu mempergunakan berbagai indikator yang telah berkembang saat ini, terutama halhal yang menyangkut tentang pemikiran kembali apa yang menjadi tujuan hukum dan redefinisi tentang fungsi dan peranan hukum dalam masyarakat. Jika kesadaran hukum masyarakat tidak merespons untuk menaati dan mematuhi peraturan hukum, maka keberlakuan peraturan hukum itu tidak akan efektif. ${ }^{14}$

Kesadaran hukum masyarakat merupakan hal yang sangat penting dan menentukan berlakunya suatu hukum dalam masyarakat. Kesadaran hukum masyarakat itu menyangkut faktor-faktor apakah suatu ketentuan hukum diketahui,

${ }^{12}$ Ibid.

${ }^{13}$ Abdul Manan, Aspek-Aspek Pengubah Hukum, Cet. III Jakarta: Kencana Prenada Media, 2006), 96.

14Ibid., 96-7. 
dipahami, diakui, dihargai dan ditaati oleh masyarakat sebagai pengguna hukum tersebut. Kesadaran hukum masyarakat merupakan unsur utama yang harus diperhitungkan dalam berfungsinya hukum secara efektif dalam masyarakat. ${ }^{15}$

Dalam upaya penegakan qanun syariat Islam di Aceh akhirakhir ini banyak sekali mengalami hambatan dan tantangan di lapangan. Sebagai contoh kasus yang terjadi baru-baru ini, upaya tim terpadu untuk membubarkan pertunjukan keyboard di Gampong Alue Merbau, Kecamatan Langsa Timur Sabtu (20/10) malam berakhir rusuh, karena mendapat perlawanan dari sekelompok pemuda yang diduga sedang mabuk. Para pemuda itu melemparkan botol minuman keras (miras) dan batu ke arah petugas yang sedang membubarkan pentas keyboard. Akibat lemparan itu, seorang anggota Wilayatul Hisbah (WH) Langsa terkena batu, sehingga harus dilarikan ke Instalasi Gawat Darurat Rumah Sakit Umum Daerah (IGD RSUD) Langsa untuk dirawat. Seluruh anggota tim lain harus lari untuk menyelamatkan diri ke komplek Dayah (Pesantren) Modern Madarasah Ulumul Quran (MUQ) Alue Pineung karena dikejar oleh kelompok pemuda yang jumlahnya tidak seimbang dengan anggota tim terpadu tersebut. Mereka terkurung selama dua jam di sana, sampai akhirnya harus dijemput oleh aparat keamanan bersenjata lengkap dari Polres Kota Langsa. ${ }^{16}$

Tim terpadu yang membubarkan pertunjukan keyboard itu terdiri atas Tim Antimaksiat Dinas Syariat Islam (DSI), Wilayatul Hisbah (WH), Polisi Militer (PM), dan Satuan Polisi Pamong Praja (Satpol PP) Langsa. Tim ini untuk menegakkan peraturan Wali Kota Langsa yang sejak Pebruari 2012 lalu melarang pertunjukan keyboard di Kota Langsa, demi untuk penegakan syariat Islam di sana. Apalagi dalam pertunjukan keyboard tersebut menampilkan biduanita yang berpakaian seksi hampir menampakkan paha kepada penonton yang terdiri dari anakanak dan orang dewasa. Pertunjukan keyboard itu diadakan oleh

15Ibid., 97.

16"WH Dilempari Botol Miras", SERAMBI INDONESIA BANDA ACEH, 22 Oktober 2012, 1. 
salah seorang warga sebagai syukuran karena anaknya diterima sebagai anggota TNI. ${ }^{17}$

Kasus itu mencerminkan bahwa masyarakat mengabaikan ketentuan hukum, sehingga sebuah aturan hukum yang semestinya dipatuhi di "Nanggroe Syariat" tidak efektif berlakunya. Hal ini terjadi karena masyarakat tidak mempunyai kesadaran hukum sebagai unsur utama dalam penegakan syariat Islam di Aceh. Dengan kondisi seperti ini dikhawatirkan penegakan syariat Islam kelak akan pudar dengan sendirinya.

Di sisi lain, beberapa hari sebelumnya Forum Pembela Rakyat Miskin (FPRM) meminta kepada Polres Langsa maupun Wilayatul Hisbah (WH) dan Dinas Syariat Islam untuk menangkap para penjual (pengedar) minuman keras (miras) di kota tersebut. Ketua FPRM Nasruddin mengatakan, penegak hukum harus mengambil tindakan tegas dan menangkap para pelaku penjual miras di Kota Langsa karena secara hukum pidana maupun Qanun Syariat Islam menjual miras adalah pelanggaran yang tidak dapat ditolerir. Dengan masih beredarnya miras otomatis akan tetap ada kemaksiatan di Kota Langsa. Apabila miras tidak diperjualbelikan, maka sudah pasti para pecandu minuman haram itu akan kelabakan dan maksiat juga bisa mereda. Menurutnya, ada sejumlah tempat yang bebas menjual miras dan sudah menjadi rahasia umum, tapi anehnya praktik yang dilakukan oknum tertentu ini tidak tersentuh oleh hukum, dan seakan-akan perdagangan miras dilegalkan, tapi yang mengonsumsikannya dilarang. ${ }^{18}$ Ini menunjukkan masyarakat yang memiliki kesadaran hukum yang tinggi, sehingga mereka tidak senang jika maksiat merajalela di bumi Aceh.

Begitu juga sebelumnya, sebanyak 11 ormas Islam di Banda Aceh mendesak Polres Kota Langsa untuk mengusut dan menangkap pelaku pengancaman terhadap Kepala Dinas Syariat Islam Kota Langsa, Ibrahim Latif, dan juga meminta Walikota Langsa untuk melindungi yang bersangkutan dari ancaman orang-orang yang diduga anti syariat Islam. Ancaman tersebut datang setelah Dinas Syariat Islam Kota Langsa gencar

${ }^{17}$ Ibid., 1 dan 11.

18“FPRM Minta Penegak Hukum Tangkap Penjual Miras", SERAMBI INDONESLA BANDA ACEH, 17 Oktober 2012, 19. 
melakukan operasi terhadap pelaku khalwat (mesum) di lapangan merdeka dan pembubaran hiburan malam (keyboard). ${ }^{19}$

Dalam waktu yang hampir bersamaan, mahasiswa yang tergabung dalam Kesatuan Aksi Mahasiswa Muslim Indonesia (KAMMI) menggelar aksi unjuk rasa di Bundaran Simpang Lima, Banda Aceh untuk menuntut dan menegaskan penolakan dan perlawanannya terhadap upaya pihak-pihak tertentu yang ingin melemahkan dan melakukan pembusukan terhadap penegakan Syariat Islam di Aceh. Unjuk rasa serupa juga terjadi di beberapa daerah di Aceh pada hari yang sama. Tema yang mereka usung sama, yaitu selamatkan Syariat Islam (Save Syariat) di Aceh. Adapun pernyataan sikap mereka, yaitu:

1. Tolak semua upaya pelemahan dan pembusukkan Syariat Islam oleh siapa pun, baik media, LSM, maupun lembaga nasional dan asing.

2. Mengecam pihak-pihak tertentu yang sengaja memojokkan dan membusukkan Syariat Islam di Aceh dengan dalih HAM dan dalih pembenar lainnya.

3. Mendesak semua unsur pemerintah Aceh, baik pemerintah provinsi maupun pemerintah kabupaten/kota untuk serius dan berkomitmen dalam menjalankan Syariat Islam serta memperkuat perangkat-perangkat pelaksanaan Syariat Islam di Aceh.

4. Mengajak semua elemen masyarakat dan para pemangku kepentingan untuk sama-sama ikut memperkuat dan mendukung proses pelaksanaan Syariat Islam di Aceh. ${ }^{20}$

\section{Qanun Syariat Islam di Aceh Ditinjau Secara Filosofis}

Selain dua landasan yangn telah diuraikan di atas, yuridis dan sosiologis, suatu produk hukum harus memiliki pula landasan filosofis. Terhadap landasan ini Bagir Manan menjelaskan bahwa dasar filosofis berkaitan dengan "rechtsidee" di mana semua masyarakat mempunyainya, yaitu apa yang mereka harapkan dari hukum, misalnya untuk menjamin keadilan, ketertiban,

19"Ormas Islam: Tangkap Pengancam Kadis Syariat Islam”, SERAMBI INDONESLA BANDA ACEH, 17 Oktober 2012, 1.

20"KAMMI: Save Syariat", SERAMBI INDONESLA BANDA ACEH, 17 Oktober 2012, 1. 
kesejahteraan dan sebagainya. Cita hukum atau rechtsidee tersebut tumbuh dari sistem nilai mereka mengenai baik atau buruk, pandangan terhadap hubungan individual dan kemasyarakatan, tentang kebendaan, kedudukan wanita dan sebagainya. Semuanya itu bersifat filosofis, artinya menyangkut pandangan mengenai hakikat sesuatu. Hukum diharapkan mencerminkan sistem nilai tersebut, baik sebagai sarana yang melindungi nilainilai maupun sebagai sarana mewujudkannya dalam tingkah laku masyarakat. Nilai-nilai ini ada yang dibiarkan dalam masyarakat sehingga setiap pembentukan hukum atau peraturan perundangundangan harus dapat menangkapnya setiap kali akan membentuk hukum atau peraturan perundang-undangan. Akan tetapi, adakalanya sistem nilai tersebut telah terangkum dalam, baik berupa teori-teori filsafat maupun dalam doktrin-doktrin resmi ${ }^{21}$ (misalnya: Alquran dan hadis dalam pemberlakuan qanun Syariat Islam di Aceh).

Maksud syara' (maqāsìd al-shar'iyyah) terhadap makhluk ada lima, yaitu memelihara agama, jiwa, akal, keturunan, dan harta mereka. Segala sesuatu yang di dalamnya terkandung pemeliharaan terhadap lima pokok tadi, maka dia disebut maslahah. Sedangkan setiap sesuatu yang dapat menghilangkan pokok-pokok itu, maka dia dinamakan mafsadah, menolaknya adalah dengan maslahah. Memelihara pokok-pokok yang lima tadi berkisar pada tingkatan kebutuhan primer (darüryyjat). Ini merupakan martabat (tingkatan) yang paling kuat di dalam maslaḥah. Misalnya, ketetapan syara' untuk membunuh orang kafir yang menyesatkan (mengganggu) orang lain dan menghukum ahli bid'ah yang mengajak orang lain untuk mengikuti bid'ahnya, maka kedua contoh ini dapat menghilangkan agama dari sisi makhluk yang bernama manusia. Keputusan mewajibkan qișạs karena dengannya dapat terpelihara jiwa seseorang. Keputusan mewajibkan hukuman bagi peminum arak karena dengannya dapat terpelihara akal yang merupakan modal paling berharga dalam pembebanan hukum. Keputusan mewajibkan hukuman zina karena dengannya akan terpelihara kemurnian keturunan. Keputusan mewajibkan hukuman bagi perampok dan pencuri karena dengannya akan terpelihara harta

${ }^{21}$ Yuliandri, Asas-Asas Pembentukan ..., 135-6. 
yang merupakan sumber kehidupan. Semua itu adalah kebutuhan primer manusia dalam menempuh kehidupannya dan haram hukumnya menghilangkan kelima pokok tadi. ${ }^{22}$

Berkaitan dengan uraian di atas, dalam pemberlakuan Syariat Islam di Aceh telah melahirkan beberapa qanun yang mengatur tentang hal itu. Qanun-qanun tersebut, yaitu Qanun Nomor 11 Tahun 2002 tentang Pelaksanaan Syariat Islam Bidang Akidah, Ibadah dan Syi'ar Islam. Qanun ini khusus dalam bidang akidah mengatur, setiap orang berkewajiban memelihara akidah dari pengaruh paham atau aliran sesat; setiap orang dilarang menyebarkan paham atau aliran sesat; dan setiap orang dilarang dengan sengaja keluar dari akidah dan atau menghina atau melecehkan agama Islam (Pasal 5). ${ }^{23}$

Tujuan dari qanun ini adalah untuk memelihara agama seseorang agar tidak menjadi ahli bid'ah dengan menjadi pengikut paham atau aliran sesat atau tidak menjadi kafir dengan keluar dari agama Islam dan menjadi pengikut agama lain. Tetapi dalam operasionalnya di lapangan qanun ini belum berjalan secara maksimal. Buktinya, belum ada satupun kasus paham atau aliran sesat atau pemurtadan oleh kaum missionaris yang terungkap di Aceh dihukum sesuai dengan aturan qanun. Padahal dalam qanun disebutkan, 'uqübah atau hukuman bagi pelaku yang menyebarkan paham atau aliran sesat dihukum dengan ta'dhir berupa hukuman penjara paling lama 2 (dua) tahun atau hukuman cambuk di depan umum paling banyak 12 (dua belas) kali. Sedangkan pelaku yang dengan sengaja keluar dari akidah Islam dan atau menghina atau melecehkan agama Islam akan dihukum dengan hukuman yang akan diatur dalam qanun tersendiri (Pasal 20). ${ }^{24}$ Sampai saat ini sepengetahuan penulis, qanun yang mengatur tentang hukuman tersebut belum lahir. Jangankan diatur, diwacana pun belum pernah.

Pemeliharaan agama merupakan tujuan pertama hukum Islam. Sebabnya adalah karena agama merupakan pedoman hidup manusia, dan di dalam agama Islam selain komponen-

${ }^{22} \mathrm{Al}$-Imām Abū Hamīd Muḥammad bin Muḥammad al-Gazālī, alMustasfā min Tlm al-Ușül (Beirut: Dār al-Kutub al-'Ilmiyah, 2008), 275-6.

23Dinas Syariat Islam, Himpunan Undang-Undang..., 304.

${ }^{24}$ Ibid., 308. 
komponen aqidah yang merupakan pegangan hidup setiap muslim serta akhlak yang merupakan sikap hidup seorang muslim, terdapat juga syariat yang merupakan jalan hidup seorang muslim, baik dalam berhubungan dengan Tuhannya maupun dalam berhubungan dengan manusia lain dan benda dalam masyarakat. Ketiga komponen itu, dalam agama Islam terikat erat. Karena itulah, maka hukum Islam wajib melindungi agama yang dianut seseorang dan menjamin kemerdekaan setiap orang untuk beribadah menurut keyakinannya. ${ }^{25}$

Kemudian, Qanun Nomor 12 Tahun 2002 tentang Minuman Khamar dan sejenisnya. Qanun ini mengatur, setiap orang dilarang mengkonsumsi minuman khamar dan sejenisnya (Pasal 5). Setiap orang atau badan hukum/badan usaha dilarang memproduksi, menyediakan, menjual, memasukkan, mengedarkan, mengangkut, menyimpan, menimbun, memperdagangkan, menghadiahkan dan mempromosikan minuman khamar dan sejenisnya; dan setiap orang atau badan hukum/badan usaha dilarang turut serta/membantu memproduksi, menyediakan, menjual, memasukkan, mengedarkan, mengangkut, menyimpan, menimbun, memperdagangkan, menghadiahkan dan mempromosikan minuman khamar dan sejenisnya (Pasal 6). Instansi yang berwenang menerbitkan izin usaha hotel, penginapan, losmen, wisma, bar, restoran, warung kopi, rumah makan, kedai, kios, dan tempat-tempat lain dilarang melegalisasikan penyediaan minuman khamar dan sejenisnya (Pasal 8). ${ }^{26}$

Ketentuan 'uqübah (hukuman)nya adalah setiap orang yang melanggar ketentuan sebagaimana dimaksud dalam pasal 5, diancam dengan 'uqübah budüd 40 (empat puluh) kali cambuk. Setiap orang yang melanggar ketentuan sebagaimana yang dimaksud dalam pasal 6 dan 8 diancam dengan 'uqübah ta'dhir berupa kurungan paling lama 1 (satu) tahun, paling singkat 3 (tiga) bulan dan atau denda paling banyak Rp. 75.000.000,(tujuh puluh lima juta rupiah), paling sedikit Rp. 25.000.000,-

${ }^{25}$ Muhammad Daud Ali, Hukum Islam; Pengantar Ilmu Hukum dan Tata Hukum Islam di Indonesia, (Jakarta: RajaGrafindo Persada, 2009), 63.

26Dinas Syariat Islam, Himpunan Undang-Undang ..., 323. 
(dua puluh lima juta rupiah) (Pasal 26 ayat 1). ${ }^{27}$ Qanun ini bertujuan untuk mengatur seseorang muslim agar memelihara akalnya supaya tidak rusak dan dapat menerima pembebanan hukum dari Allah dan Rasul-Nya. Juga untuk mencegah terjadinya tindak perbuatan maksiat lainnya akibat hilangnya akal (rusak akal akibat mabuk) setelah mengonsumsi minuman beralkohol tersebut. Namun dalam operasionalnya akhir-akhir ini tidak begitu efektif dan banyak tantangan di lapangan.

Pemeliharaan akal sangat dipentingkan oleh hukum Islam, karena dengan mempergunakan akalnya, manusia dapat berpikir tentang Allah, alam semesta dan dirinya sendiri. Dengan mempergunakan akalnya manusia dapat mengembangkan ilmu pengetahuan dan teknologi. Tanpa akal, manusia tidak mungkin pula menjadi pelaku dan pelaksana hukum Islam. Oleh karena itu, pemeliharaan akal menjadi salah satu tujuan hukum Islam. Penggunaan akal itu harus diarahkan pada hal-hal atau sesuatu yang bermanfaat bagi kepentingan hidup manusia, tidak untuk hal-hal yang merugikan kehidupan. Untuk memelihara akal itulah, maka hukum Islam melarang orang meminum setiap minuman yang memabukkan yang disebut dengan istilah khamar dalam al-Qur'an (Qs. al-Maidah [5]:90) dan menghukum setiap perbuatan yang dapat merusak akal manusia. ${ }^{28}$

Selanjutnya, Qanun Nomor 13 Tahun 2002 tentang Maisir (Perjudian). Qanun ini mengatur tentang setiap orang dilarang melakukan perbuatan maisir (Pasal 5). Setiap orang atau badan hukum atau badan usaha dilarang menyelenggarakan dan atau memberikan fasilitas kepada orang yang akan melakukan perbuatan maisir; setiap orang atau badan hukum atau badan usaha dilarang menjadi pelindung terhadap perbuatan maisir (Pasal 6). Instansi Pemerintah dilarang memberi izin usaha penyelenggaraan maisir (Pasal 7). ${ }^{29}$

Adapun ketentuan 'uqübah-nya adalah setiap orang yang melanggar ketentuan sebagaimana dimaksud dalam pasal 5, diancam dengan 'uqübah cambuk di depan umum paling banyak 12 (dua belas) kali dan paling sedikit 6 (enam) kali. Setiap orang

${ }^{27}$ Ibid., 327-8.

${ }^{28}$ Muhammad Daud Ali, Hukum Islam..., 63-4.

${ }^{29}$ Dinas Syariat Islam, Himpunan Undang-Undang ..., 339. 
atau badan hukum atau badan usaha Non Instansi Pemerintah yang melanggar ketentuan sebagaimana dimaksud dalam pasal 6 dan 7, diancam dengan 'uqübah atau denda paling banyak Rp. 35.000.000,- (tiga puluh lima juta rupiah), paling sedikit Rp. 15.000.000,- (lima belas juta rupiah) (Pasal 23 ayat 1 dan 2). ${ }^{30}$ Tujuan dari qanun ini adalah untuk memelihara harta seseorang agar diperoleh dengan cara yang halal dan memanfaatkannya juga dengan jalan yang halal, sebagaimana tuntunan syariat. Tetapi akhir-akhir ini qanun ini juga kurang efektif dalam operasionalnya, khususnya dalam bidang pengawasan dan pembinaan, sebagaimana diamanahkan oleh qanun.

Pemeliharaan harta adalah salah satu tujuan hukum Islam. Menurut ajaran Islam, harta adalah pemberian Tuhan kepada manusia, agar manusia dapat mempertahankan hidup dan melangsungkan kehidupannya. Oleh karena itu, hukum Islam melindungi hak manusia untuk memperoleh harta dengan caracara yang halal dan sah, maka hukum Islam melarang seseorang untuk berjudi (maisir) dan mengundi nasib (Qs. al-Maidah [5]: 90) serta melindungi kepentingan harta seseorang, masyarakat dan negara, misalnya dari penipuan (Qs. al-Nisa' [4]: 29), penggelapan/korupsi (Qs. al-Nisa' [4]: 58), perampasan (Qs. alMaidah [5]: 33), pencurian (Qs. al-Maidah [5]: 38), dan kejahatan lain terhadap harta orang lain. ${ }^{31}$

Terakhir, Qanun Nomor 14 Tahun 2002 tentang khalwat (mesum). Qanun ini mengatur, setiap orang dilarang melakukan khalwat/mesum (Pasal 5). Setiap orang atau kelompok masyarakat, atau aparatur pemerintahan dan badan usaha dilarang memberikan fasilitas kemudahan/atau melindungi orang melakukan khalwat/mesum (Pasal 6). ${ }^{32}$ Adapun ketentuan uqübah-nya adalah setiap orang yang melanggar ketentuan sebagaimana dimaksud dalam pasal 5, diancam dengan 'uqübah ta'dhir berupa dicambuk paling tinggi 9 (sembilan) kali, paling rendah 3 (tiga) kali dan atau denda paling banyak Rp. 10.000.000,- (sepuluh juta rupiah), paling sedikit Rp. 2.500.000,(dua juta lima ratus ribu rupiah). Setiap orang yang melanggar

${ }^{30}$ Ibid., 343.

${ }^{31}$ Muhammad Daud Ali, Hukum Islam ..., 64-5.

32Dinas Syariat Islam, Himpunan Undang-Undang ..., 356. 
ketentuan sebagaimana dimaksud dalam pasal 6 diancam dengan 'uqübah ta'dhì berupa kurungan paling lama 6 (enam) bulan, paling singkat 2 (dua) bulan dan atau denda paling banyak Rp. 15.000.000,- (lima belas juta rupiah), paling sedikit Rp. 5.000.000,- (lima juta rupiah) (Pasal 22 ayat 1 dan 2). ${ }^{33}$

Tujuan dari qanun ini adalah untuk memelihara seseorang agar tidak terjerumus ke dalam perbuatan zina, yang berakibat kepada terjadinya kekaburan dalam hal kemurnian keturunan. Tetapi, menurut penulis Pemerintah Aceh perlu segera mengesahkan qanun jinayat yang di dalamnya mengatur tentang hukuman bagi pelaku zina. Karena dari sekian banyak kasus khalwat/mesum yang terungkap banyak pelakunya yang mengaku telah melakukan perbuatan zina. Namun, karena qanun yang mengatur tentang hal itu belum ada, maka pelakunya hanya sebatas dihukum dengan hukuman ta'dhir. Padahal menurut syariat Islam, pelakunya mesti dihukum dengan hukuman cambuk 100 (seratus) kali bagi gayr mubsan (belum pernah menikah) dan hukuman rajam (hukuman mati dengan cara dilempari batu) bagi pelaku mubșan (sudah pernah menikah dan melakukan hubungan intim dalam nikahnya tersebut). Begitu juga Pemerintah Aceh perlu menyusun dan mengesahkan qanun yang mengatur tentang qișass supaya terpelihara jiwa seseorang dari terjadinya pembunuhan, baik disengaja maupun tidak. Perlu pula qanun yang mengatur tentang hukuman bagi pencuri atau perampok supaya terpelihara harta seseorang dari penguasaan orang-orang secara tidak berhak.

\section{Catatan Akhir}

Dalam membuat suatu produk hukum yang berupa qanun di Aceh, khususnya qanun yang berkaitan dengan penegakan syariat Islam haruslah mengacu kepada tiga landasan, yaitu landasan yuridis, sosiologis, dan filosofis. Landasan yuridis produk qanun tentang penerapan Syariat Islam di Aceh adalah Undang-undang Dasar Negara Republik Indonesia 1945, Undang-undang Nomor 44 Tahun 1999 tentang Penyelenggaraan Keistimewaan Daerah Istimewa Aceh, kemudian disempurnakan dengan Undang-undang Nomor 18

${ }^{33} I b i d ., 360$. 
Tahun 2001 tentang Otonomi Khusus bagi Provinsi Daerah Aceh sebagai Provinsi NAD. Terakhir Undang-undang Republik Indonesia Nomor 11 Tahun 2006 tentang Pemerintahan Aceh (UUPA). Hakikatnya secara yuridis, syariat Islam sebenarnya merupakan sistem nilai yang paling rinci mengatur kehidupan manusia mulai persoalan individual, keluarga sampai kepada kehidupan sosial.

Adapun landasan sosiologisnya adalah mayoritas masyarakat Aceh yang beragama Islam dapat menerima semua produk hukum yang berdasarkan syariat Islam tersebut. Hal ini terbukti dengan adanya tuntutan-tuntutan dari berbagai elemen masyarakat untuk mendukung penerapan syariat Islam di Aceh. Di sisi lain Syariat Islam dalam perjalanan sejarah rakyat Aceh telah dijadikan sebagai living law, dalam masyarakat. Sedangkan landasan filosofisnya adalah syariat Islam perlu ditegakkan berdasarkan anjuran al-Qur'an dan hadis. Karena syariat Islam memiliki kandungan yang sarat dengan tema keadilan, dan cocok dengan fitrah manusia. Tujuan dari pensyariatan hukum Islam adalah untuk memelihara agama, memelihara jiwa, memelihara akal, memelihara keturunan, dan memelihara harta. Oleh karenanya, penegakan syariat Islam di Aceh dengan melahirkan qanun-qanun yang mengatur semua aspek syariat adalah hal yang mutlak diperlukan.

\section{Daftar Pustaka}

Abubakar, Al Yasa‘. 2008. Syariat Islam di Provinsi Nanggroe Aceh Darussalam; Paradigma, Kebijakan dan Kegiatan. Edisi 5. Banda Aceh: Dinas Syariat Islam Provinsi NAD.

Ali, Muhammad Daud. 2009. Hukum Islam; Pengantar Ilmu Hukum dan Tata Hukum Islam di Indonesia. Jakarta: RajaGrafindo Persada.

Dinas Syariat Islam, 2009. Himpunan Undang-Undang, Keputusan Presiden, Peraturan Daerah/Qanun, Instruksi Gubernur, Edaran Gubernur Berkaitan Pelaksanaan Syariat Islam. Edisi 7. Banda Aceh: Dinas Syariat Islam Aceh. 
"FPRM Minta Penegak Hukum Tangkap Penjual Miras". SERAMBI INDONESLA BANDA ACEH. 17 Oktober 2012. 19.

al-Ghazālī, al-Imām Abū Ḥāmid Muḥammad bin Muḥammad. 2008. Al-Mustasfā min 'Ilmi al-Ușūl. Beirut: Dār al-Kutub al'Ilmiyah.

"KAMMI: Save Syariat", SERAMBI INDONESLA BANDA ACEH. 17 Oktober 2012. 1.

Manan, Abdul. 2006. Aspek-Aspek Pengubab Hukum. Cet. III. Jakarta: Kencana Prenada Media.

"Ormas Islam: Tangkap Pengancam Kadis Syariat Islam", SERAMBI INDONESLA BANDA ACEH. 17 Oktober 2012. 1.

Shobari, Choiruddin. dkk. 2009. "Penyerapan Nilai-nilai Budaya Lokal Dalam Kehidupan Beragama di Aceh (Studi Tentang Budaya Lokal di Aceh)", dalam Harmonisasi Agama dan Budaya di Indonesia (2). ed. Afif dan Saiful Bahri. Jakarta: Balai Penelitian dan Pengembangan Agama.

Undang-Undang Dasar Republik Indonesia 1945 (Amandemen Oktober 1999 dan Agustus 2000).

Undang-Undang Republik Indonesia Nomor 11 Tahun 2006 Tentang Pemerintahan Aceh.

"WH Dilempari Botol Miras", SERAMBI INDONESLA BANDA ACEH. 22 Oktober 2012. 1 dan 11.

Yuliandri, 2010. Asas-Asas Pembentukan Peraturan PerundangUndangan Yang Baik; Gagasan Pembentukan Undang-Undang Berkelanjutan. Cet. ke-2. Jakarta: RajaGrafindo Persada. 